\title{
PENGEMBANGAN BAHAN AJAR MEMBACA PEMAHAMAN \\ BERDASARKAN STRATEGI PLAN (PREDICT, LOCATE, ADD, NOTE) UNTUK SISWA KELAS VII
}

\author{
Sudiati dan Nurhidayah \\ Fakultas Bahasa dan Seni Universitas Negeri Yogyakarta \\ email: sudiati66@gmail.com
}

\begin{abstract}
Abstrak
Penelitian ini bertujuan menghasilkan bahan ajar membaca pemahaman berdasarkan strategi PLAN dan mengetahui kelayakannya untuk siswa kelas VII. Penelitian ini termasuk jenis penelitian desain dan pengembangan. Tahapan yang digunakan diambil dari gagasan Borg dan Gall. Jenis data berupa kualitatif dan kuantitatif. Uji keabsahan data berupa uji kredibilitas, transferabilitas, dependabilitas, dan konfirmabilitas. Instrumen penelitian berupa pedoman wawancara dan angket. Teknik analisis data yang digunakan adalah analisis kualitatif dan statistik deskriptif. Hasil penelitian berupa buku ajar membaca pemahaman yang terdiri dari pendahuluan, isi, dan pelengkap. Hasil uji ahli materi dan ahli pembelajaran menunjukkan buku ajar yang dikembangkan berkategori baik dari aspek kelayakan isi, penyajian, bahasa, dan kegrafikaan. Hal ini ditunjukkan oleh skor rata-rata dari ahli materi sebesar 3,78 dan ahli pembelajaran sebesar 3,80.
\end{abstract}

Kata kunci: bahan ajar, membaca pemahaman, strategi PLAN

\section{DEVELOPING READING COMPREHENSION LEARNING MATERIALS BASED ON THE PLAN (PREDICT, LOCATE, ADD, NOTE) STRATEGY FOR GRADE VII STUDENTS}

\begin{abstract}
This study aims to produce reading comprehension learning materials based on the PLAN strategy and to find out the appropriateness for Grade VII students. This was a design and development study. The stages were taken from those of Borg and Gall. The data were qualitative and quantitative in nature. The data trustworthiness was assessed in terms of credibility, transferability, dependability, and confirmability. The research instruments were an interview guide and a questionnaire. The data were analyzed by the qualitative technique and descriptive statistics. The research product is a reading comprehension course book consisting of an introduction, contents, and a supplement. The results of the evaluation by the the materials expert and the learning expert show that the developed course book is good in terms of content appropriateness, presentation, language, and graphics. These are indicated by a mean score of 3.78 from the the materials experts and 3.80 from the the learning expert.
\end{abstract}

Keywords:learning materials, reading comprehension, PLAN strategy

\section{PENDAHULUAN}

Membaca merupakan salah satu keterampilan berbahasa yang sangat penting yang harus dikuasai oleh siswa. Di sam- ping mendengarkan, yaitu pintu utama pengetahuan dan pengalaman yang diperoleh secara auditif, keterampilan membaca juga merupakan pintu utama penge- 
tahuan dan pengalaman baru yang diperoleh secara visual. Sebagai keterampilan reseptif, membaca memiliki potensi yang sangat besar dalam pemerolehan pengetahuan dan pengalaman itu. Membaca merupakan salah satu keterampilan literasi, di samping keterampilan menulis. Keterampilan literasi itu meliputi pengetahuan dan keterampilan yang dapat diperoleh dan dikuasai siswa dalam beberapa tingkatan literasi, yaitu tingkat performatif, fungsional, informasional, dan epistemis.

Namun demikian, menurut laporan UNESCO (melalui PISA, 2003), keterampilan membaca anak-anak Indonesia yang berusia 15 tahun ke atas berada pada urutan ke-39 dari 41 negara yang diteliti. Dari jumlah subjek yang diteliti, sebanyak $37,6 \%$ siswa dinyatakan bisa membaca, tetapi tidak bisa menangkap atau memahami makna dan hanya sebanyak $24,8 \%$ siswa yang bisa mengambil satu kesimpulan pengetahuan. Hal itu juga didukung oleh hasil penelitian yang dilakukan IEA Study of Reading Literacy (Elly, 1992) dan Progress in International Reading Literacy Study (2006) yang menyatakan bahwa kemampuan membaca anak-anak sekolah dasar di Indonesia masih sangat rendah.

Di samping itu, hasil penelitian yang dilakukan PIRLS (2006) menghasilkan beberapa simpulan yang juga mengarah pada rendahnya kemampuan membaca siswa sekolah dasar di Indonesia. Hasil penelitian itu menunjukkan bahwa (i) skor prestasi membaca siswa sekolah dasar di Indonesia adalah 407, sementara skor rata-rata negara peserta 500, (ii) hanya $2 \%$ siswa sekolah dasar di Indonesia yang prestasi membacanya masuk ke dalam kategori sangat tinggi, sedangkan 19\% di antaranya masuk kategori menengah, dan 55\% masuk kategori rendah, serta (iii) sebanyak $45 \%$ siswa Indonesia tidak dapat mencapai skor 400.

Pada kesempatan yang berbeda, hasil penelitian PIRLS (2011) menyebutkan bahwa kemampuan membaca anak-anak sekolah dasar di Indonesia menduduki posisi ke-42 di antara 45 negara yang diteliti, dengan rerata skor 48. Hal ini berarti kemampuan membaca anak-anak Indonesia masih rendah. Berita yang dilansir oleh Harian Umum Pikiran Rakyat (23 Maret 2004) menyatakan bahwa kondisi ideal surat kabar yang harus dibaca ialah 1:10. Berdasarkan berita itu, Indonesia berada pada posisi yang masih sangat rendah, yaitu 1:45, dan masih jauh di bawah Philipina (1:30) dan Sri Langka (1:38). Sumber lain juga menyatakan bahwa kemampuan membaca dan menulis anakanak Indonesia berada pada peringkat paling bawah apabila dibandingkan dengan anak-anak Asia (Supriyoko, 2004).

Jika disinyalir, rendahnya budaya baca-tulis disebabkan oleh lemahnya sistem pembelajaran di sekolah. Artinya, sistem pendidikan di Indonesia dianggap belum berhasil mengajarkan keterampilan baca-tulis kepada para siswa (A. Chaedar Alwasilah, 2005). Dalam pembelajaran membaca dan menulis, para guru masih mengandalkan kurikulum nasional dan buku paket untuk materi ajar dan metodologinya, sementara pemodelan dalam kegiatan membaca dan menulis tidak lazim dilakukan oleh guru (Setiadi, 2010).

Membaca merupakan "the process of simultaneously extracting and constructing meaning through interaction and involvement with written language (Cladwell, 2008), yaitu proses yang terjadi secara bersama-sama dalam mengekstrasi dan mengonstruksi makna melalui interaksi dan keterlibatan dengan bahasa tulis. Dalam membaca ada tiga unsur penting yang saling bekerja sama, yaitu bahan bacaan, pembaca, dan penulis. Pembaca berusaha memahami bacaan yang ditulis oleh penulis melalui berbagai cara agar bermanfaat bagi dirinya. Jadi, membaca bukan merupakan kegiatan yang sederhana. Membaca digolongkan sebagai keterampilan yang melibatkan proses mengekstrasi, menego- 
siasikan, dan mengonstruksi makna yang terkandung dalam bacaan (Darmiyati Zuchdi, 2012).

Sehubungan dengan pembelajaran membaca, selama ini, pembelajaran membaca lebih ditekankan pada hasil yang berupa jawaban atas pertanyaan-pertanyaan bacaan. Siswa langsung melakukan praktik membaca tanpa belajar bagaimana cara membaca. Pada pelaksanaan pembelajaran, pada umumnya guru meminta siswa untuk membaca sesuai dengan kompetensi dasar yang ada dalam kurikulum. Setelah selesai, guru memberikan penilaian atas pekerjaan siswa. Kegiatan tersebut terus-menerus dilakukan di dalam pembelajaran, sehingga siswa merasa bosan dan tidak bergairah untuk mengikuti pembelajaran membaca. Hal ini mengakibatkan keterampilan membaca siswa rendah.

Terkait dengan kondisi tersebut, salah satu upaya yang dapat dilakukan untuk meningkatkan kualitas pembelajaran membaca adalah dengan melakukan inovasi model pembelajaran, salah satunya adalah pengembangan bahan ajar melalui penerapan strategi PLAN (predict, locate, add, note). Strategi PLAN cocok dalam pembelajaran membaca pemahaman karena mampu menstimulasi siswa untuk berpikir aktif. Strategi PLAN dirancang agar siswa melakukan kegiatan membaca melalui proses yang lengkap sehingga dapat menyerap informasi secara menyeluruh dan mendalam.

Materi pembelajaran merujuk pada segala sesuatu yang digunakan oleh guru dan siswa untuk memfasilitasi pembelajaran. Materi pembelajaran bahasa mencakup buku teks pelajaran, buku kerja siswa, kaset, piringan hitam, rekaman video, bahan hasil foto kopi, surat kabar, dan lain-lain (Tomlinson, 1998: 20). Materi pembelajaran bahasa pada dasarnya merupakan segala macam sumber bahan yang dapat membantu pembelajaran bahasa (Waters, 2009: 311).
Menurut Crawford (2002: 44-47), materi pembelajaran bahasa yang efektif hendaknya didasari oleh beberapa pandangan berikut: (i) bahasa bersifat fungsional dan kontekstula, (ii) pengembangan bahasa memerlukan kesepakatan pembelajar bahasa dalam konteks penggunaan, (iii) penggunaan bahasa bersifat realistik dan otentik, (iv) materi pembelajaran juga mencakup komponen audio-visual, (v) dalam kehidupan modern dengan berbagai kemajuan teknologi, pembelajar perlu mengembangkan kemampuan terkait dengan genre teks tertulis seperti halnya genre teks lisan, (vi) materi pembelajaran yang efektif memperluas kemandirian siswa dalam belajar, (vii) materi pembelajaran perlu bersifat fleksibel dengan memperhatikan perbedaan konteks dan individu siswa, dan (viii) pembelajaran perlu mengikutsertakan siswa secara kognitif dan afektif.

Bahan ajar merupakan salah satu sumber belajar yang menjadi acuan pembelajaran. Bahan ajar yang menjadi acuan wajib pembelajaran adalah bku teks pelajaran. Buku teks pelajaan digunakan di satuan pendidikan dasar dan menengah. Buku teks pelajaran disusun berdasar standar isi satuan pendidikan (Suryaman, 2012:110111). Bahan ajar memiliki beragam jenis baik cetak maupun noncetak. Bahan ajar cetak berupa buku, modul, dan handout. Bahan ajar noncetak meliputi bahan ajar audio, audio visual, dan multimedia interaktif.

Ada berbagai persyaratan yang harus dipenuhi dalam mengembangkan bahan ajar. Persyaratan tersebut digunakan sebagai upaya untuk membantu siswa dalam membangun pola berpikir ilmiah. Persyaratn tersebut diwujudkan ke dalam beberapa prinsip (Kurniasih dan Sani, 2014:25-27). Prinsip-prinsip tersebut adalah: (i) Kompetensi Dasar (KD) dari Kompetensi Inti (KI) diintegrasikan pada satu unit, (ii) gambar, perkataan, serta kutipan dapat menumbuhkan sikap positif, (iii) 
menumbuhkan minat dan rasa ingin tahu siswa, (iv) keseimbangan tugas individu dan kelompok, (v) kecakupan dan kecukupan materi untuk memahami dan melakukan kompetensi dasar (KD), (vi) melibatkan orang tua dan jejaring (tugas pengayaan dari berbagai sumber).

Untuk mendapatkan bahan ajar yang sesuai perlu dilakukan penilaian terhadap bahan ajar yang telah disusun. Penilaian bahan ajar dilakukan dengan menggunakan instrumen penilaian yang sesuai. Dalam kaitannya dengan penilaian bahan ajar, BSNP bersama PUSKURBUK telah mengembangkan instrumen penilaian bahan ajar yang digunakan untuk menentukan kelayakan sebuah buku teks untuk dapat dikategorikan sebagai buku yang memenuhi standar. Kriteria buku standar menurut instrumen tersebut adalah jika memenuhi empat unsur kelayakan, yaitu isi, penyajian, kebahasaan, dan kegrafikaan (Muslich, 2010:291).

Membaca termasuk dalam kompetensi berbahasa aktif reseptif. Kompetensi berbahasa aktif reseptif adalah kemampuan menerima dan memahami bahasa dari pihak lain yang disampaikan melalui tulisan untuk berbagai keperluan (Nurgiyantoro, 2011:55). Membaca merupakan proses konstruktif untuk mendapatkan pesan yang melibatkan pembaca, teks, dan tujuan sesuai konteks (Tomkins, 2010). Di samping itu, membaca merupakan proses yang terjadi secara bersama-sama dalam mengekstrasi dan mengonstruksi makna melalui interaksi dan keterlibatan dengan bahasa tulis (Cladwell, 2008:4).

Pendapat tersebut senada dengan Rudell (2005:31) yang mengemukakan bahwa membaca merupakan aktivitas mengostruksi makna yang diperoleh saat membaca sebuah teks. Seperti dikemukakan Zuchdi (2008:4) hakikat kegiatan membaca adalah memperoleh makna yang tepat. Oleh karena itu, pembaca harus memanfaatkan informasi yang dimilikinya dan mampu menghubungkan- nya dengan informasi yang baru yang ada dalam bacaan sehingga pembaca mampu menangkap pesan dari bacaan sesuai maksud penulis.

Membaca pemahaman disebut juga sebagai membaca komprehensi. Menurut Ruddell (2005:89), komprehensi terhadap teks adalah hasil dari hubungan antara pengalaman terdahulu dengan informasi dalam teks tersebut. Membaca pemahaman juga merupakan suatu proses pemerolehan makna yang secara aktif melibatkan pengetahuan dan pengalaman yang telah dimiliki oleh pembaca serta dihubungkan dengan isi bacaan.

Dalam kaitannya dengan pemahaman, Pearson dan Johnson via Sumarwati dan Purwadi (2010:5) menyatakan bahwa inti pemahaman berkaitan dengan satu prinsip yang sederhana sebagai upaya membangun jembatan antara yang baru dengan yang sudah diketahui. Hal ini dengan pendapat Somadayo (2011:10) bahwa membaca pemahaman merupakan suatu proses pemerolehan makna yang secara aktif melibatkan pengetahuan dan pengalaman yang telah dimiliki oleh pembaca serta dihubungkan dengan isi bacaan.

Nuriadi (2008: 64) menjelaskan bahwa membaca pada dasarnya bertujuan untuk mencari dan memperoleh pesan atau memahami makna melalui bacaan. Oleh karena itu, pembaca memerlukan pengetahuan tentang strategi membaca untuk mempermudah proses pemaknaan teks. Salah satu strategi membaca yang dapat diterapkan dalam pembelajaran membaca pemahaman adalah PLAN.

PLAN merupakan strategi yang tepat dalam pembelajaran membaca khususnya untuk meningkatkan pemahaman siswa terhadap teks sains atau nonsastra (Cohen dan Cowen, 2008: 219). Barton, dkk (via Yanda dan Siska, 2013: 4) berpendapat bahwa PLAN mampu mendorong siswa untuk mengevaluasi informasi yang diketahui tentang topik bacaan. Selain itu, 
PLAN juga memberikan kesempatan pada siswa untuk menjelaskan dan mengelaborasi pengetahuan yang telah mereka miliki dengan informasi yang baru saja diperoleh dari teks.

\section{METODE}

Penelitian ini termasuk jenis penelitian desain dan pengembangan yang menggunakan metode campuran. Tahapan yang digunakan dalam penelitian ini diambil dari gagasan Borg dan Gall (1983:775), yaitu, (1) studi pendahuluan,(2) perencanaan, (3) pengembangan model-awal, (4) uji coba model awal, (5) revisi model awal, (6) revisi model utama, (7) uji coba model utama, (8) revisi model operasional, (9) uji coba model operasional, (10) revisi model akhir, dan (11) desiminasi.

Jenis data yang dikumpulkan dalam penelitian pengembangan ini meliputi data kualitatif dan kuantitatif. Validitas dan reliabilitas dalam penelitian ini dilakukan melalui uji kredibilitas, transferabilitas, dependabilitas, dan konfirmabilitas. Instrumen penelitian berupa wawancara dan angket. Instrumen penelitian tersebut digunakan untuk mengumpulkan data dari kelompok ahli dan guru. Teknik analisis data yang digunakan dalam penelitian ini adalah analisis kualitatif dan analisis statistik deskriptif.

\section{HASIL DAN PEMBAHASAN}

Produk pengembangan dalam penelitian ini berupa Buku Ajar Membaca Pemahaman Berdasarkan Strategi PLAN untuk Siswa SMP Kelas VII. Buku ajar ini terdiri atas bagian pendahuluan, isi, dan pelengkap. Bagian pendahuluan berupa kulit atau sampul buku, kata pengantar, dan daftar isi, dan berkenalan dengan strategi PLAN. Bagian isi terdiri atas enam unit pelajaran membaca pemahaman, yaitu: (1) teks deskripsi, (2) teks cerita fantasi, (3) teks prosedur, (4) teks laporan hasil observasi, (5) teks fabel/legenda, dan (6) surat dinas. Bagian pelengkap berisi daftar pustaka dan glosarium. Setiap unit pelajaran disusun berdasar langkah-langkah strategi PLAN yang terdiri atas beberapa tahap, yakni memprediksi, menempatkan, membaca, menambahkan, dan mencatat. Bahan ajar ini juga dilengkapi dengan latihan pada setiap unit pelajaran.

\section{Analisis Validasi Produk oleh Ahli Ma- teri dan Ahli Pembelajaran}

Penilaian oleh para ahli dan responden dilakukan dengan pengklasifikasian interval empat. Data yang diperoleh dari masing-masing aspek yang telah dikembangkan menjadi indikator-indikator kemudian dianalisis. Rata-rata skor terakhir yang diperoleh dikonversikan menjadi data kualitatif untuk mengetahui tingkat kelayakan tiap aspek.

Langkah-langkah dalam menganalisis validasi produk oleh ahli materi dan ahli pembelajaran adalah sebagai berikut.

a. Data kuantitatif dari skala likert pada lembar validasi ahli diubah menjadi data kualitatif

b. Menjumlahkan skor untuk setiap butir aspek penilaian dari seluruh subjek penelitian.

c. Menghitung skor total rata-rata dari setiap aspek dengan rumus

$$
\bar{x}=\frac{\sum x}{n}
$$

d. Mengubah skor rata-rata menjadi nilai berupa kategori berdasarkan pedoman konversi skala empat sebagai berikut.

Tabel 1. Konversi Data Kuantitatif menjadi Data Kualitatif

\begin{tabular}{ccccc}
\hline No. & $\begin{array}{c}\text { Rentang } \\
\text { Skor }\end{array}$ & Nilai & Persentase & Kategori \\
\hline 1. & $\bar{x}>3,4$ & A & $76 \%-100 \%$ & Baik \\
2. & $2,6<\bar{x} \leq 3,4$ & B & $52 \%-76 \%$ & Cukup \\
3. & $1,8 \leq \bar{x} \leq 2,6$ & C & $36 \%-52 \%$ & Kurang \\
4. & $\bar{x} \leq 1,8$ & D & $0 \%-36 \%$ & Tidak Baik \\
\hline
\end{tabular}


Keterangan:

Presentase keidealan tiap aspek=

$\frac{\sum \text { skor rata-rata }}{\sum \text { skor maksimal tiap aspek }} \times 100 \%$

Presentase keidealan keseluruhan $=$

Sskor rata-ratakeseluruhan

$\frac{\sum \text { skor maksimal keseluruhan }}{\sum 100 \%}$

Dalam penelitian ini, nilai kelayakan ditentukan dengan nilai minimal " $B$ " yaitu kategori "cukup". Jadi, jika hasil penilaian oleh ahli materi dan ahli pembelajaran rata-ratanya memberikan nilai akhir "B" atau "cukup", maka produk pengembangan buku ajar memahami isi teks-teks pembelajaran kelas VII SMP/
MTs dengan menggunakan strategi PLAN ini dianggap layak digunakan.

\section{Hasil Penilaian Produk oleh Ahli Ma- teri}

Uji validasi pada produk ini dilakukan menggunakan lembar angket/kuesioner yang di dalamnya meliputi aspek-aspek penilaian yaitu aspek kelayakan isi, aspek kelayakan bahasa, aspek kelayakan penyajian, dan aspek kelayakan kegrafikan. Uji validasi produk dilakukan oleh ahli materi. Berikut ini disajikan hasil validasi dalam tiap aspek.

\section{Aspek Kelayakan Isi}

Berdasarkan Tabel 2, hasil validasi ahli materi pada aspek kelayakan isi dapat disimpulkan bahwa validasi ahli materi

Tabel 2. Data Validasi Ahli Materi 1 dan 2 pada Aspek Kelayakan Isi

\begin{tabular}{|c|c|c|c|}
\hline \multirow[b]{2}{*}{ No. } & \multirow[b]{2}{*}{ Indikator Penilaian } & \multicolumn{2}{|c|}{ Skor } \\
\hline & & $\begin{array}{c}\text { Ahli } \\
\text { Materi 1 }\end{array}$ & $\begin{array}{c}\text { Ahli } \\
\text { Materi } 2\end{array}$ \\
\hline 1. & Kelengkapan materi & 4 & 4 \\
\hline 2. & Keluasan materi & 4 & 4 \\
\hline 3. & Kedalaman materi & 3 & 4 \\
\hline 4. & Akurasi konsep dan definisi & 4 & 4 \\
\hline 5. & Akurasi prinsip & 4 & 4 \\
\hline 6. & Akurasi prosedur & 4 & 4 \\
\hline 7. & Akurasi contoh, fakta, dan ilustrasi & 4 & 4 \\
\hline 8. & Akurasi soal atau penugasan & 4 & 4 \\
\hline 9. & Kesesuaian dengan perkembangan ilmu dan teknologi & 3 & 4 \\
\hline 10. & Keterkinian fitur, contoh, dan rujukan & 4 & 4 \\
\hline 11. & Penalaran & 3 & 4 \\
\hline 12. & Pemecahan masalah & 3 & 4 \\
\hline 13. & Keterkaitan antar-konsep & 4 & 4 \\
\hline 14. & Komunikasi & 4 & 4 \\
\hline 15. & Penerapan & 4 & 4 \\
\hline 16. & Kemenarikan materi & 3 & 3 \\
\hline 17. & Mendorong untuk mencari informasi lebih jauh & 3 & 4 \\
\hline 18. & Materi pengayaan & 4 & 4 \\
\hline & Jumlah & 66 & 71 \\
\hline & Skor Rata-Rata & 3,67 & 3,94 \\
\hline & Persentase & $91,67 \%$ & $98,61 \%$ \\
\hline & Kategori & Baik & Baik \\
\hline
\end{tabular}


Tabel 3. Data Validasi Ahli Materi 1 dan 2 pada Aspek Kelayakan Penyajian

\begin{tabular}{|c|c|c|c|}
\hline \multirow{2}{*}{ No. } & \multirow{2}{*}{ Indikator Penilaian } & \multicolumn{2}{|c|}{ Skor } \\
\hline & & Ahli Materi 1 & Ahli Materi 2 \\
\hline 1. & Sistematika penyajian & 4 & 4 \\
\hline 2. & Keruntutan penyajian & 4 & 4 \\
\hline 3. & Keseimbangan antar-bab & 4 & 4 \\
\hline 4. & Berpusat pada siswa & 4 & 4 \\
\hline 5. & Berpikir kritis, kreatif, atau inovatif & 4 & 4 \\
\hline 6. & Kata Pengantar & 4 & 4 \\
\hline 7. & Daftar Isi & 4 & 4 \\
\hline 8. & Gambar, ilustrasi, atau tabel & 3 & 3 \\
\hline 9. & Rujukan & 3 & 4 \\
\hline 10. & Soal atau latihan & 4 & 4 \\
\hline 11. & Daftar Pustaka & 4 & 4 \\
\hline 12. & Glosarium (daftar istilah) & 4 & 4 \\
\hline 13. & Petunjuk pengerjaan soal/latihan & 3 & 4 \\
\hline & Jumlah & 49 & 51 \\
\hline & Skor Rata-Rata & 3,77 & 3,92 \\
\hline & Persentase & $94,23 \%$ & $98,08 \%$ \\
\hline & Kategori & Baik & Baik \\
\hline
\end{tabular}

Tabel 4. Data Validasi Ahli Materi 1 dan 2 pada Aspek Kelayakan Bahasa

\begin{tabular}{|c|c|c|c|}
\hline \multirow[b]{2}{*}{ No. } & \multirow[b]{2}{*}{ Indikator Penilaian } & \multicolumn{2}{|c|}{ Skor } \\
\hline & & $\begin{array}{c}\text { Ahli } \\
\text { Materi 1 }\end{array}$ & $\begin{array}{c}\text { Ahli } \\
\text { Materi } 2\end{array}$ \\
\hline 1. & Kesesuaian dengan tingkat perkembangan intelektual & 4 & 4 \\
\hline 2. & Kesesuaian dengan tingkat sosial emosional & 4 & 4 \\
\hline 3. & Keterbacaan pesan & 4 & 4 \\
\hline 4. & Ketepatan kaidah bahasa & 3 & 3 \\
\hline 5. & Keruntutan dan keterpaduan antar-bab & 4 & 4 \\
\hline 6. & Keruntutan dan keterpaduan antar-paragraf & 4 & 4 \\
\hline & Jumlah & 23 & 23 \\
\hline & Skor Rata-Rata & 3,83 & 3,83 \\
\hline & Persentase & $95,83 \%$ & $95,83 \%$ \\
\hline & Kategori & Baik & Baik \\
\hline
\end{tabular}

1 memperoleh skor rata-rata sebesar 3,67 atau persentase sebesar $91,67 \%$ dengan kategori "baik", sedangkan pada validasi ahli materi 2 memperoleh skor rata-rata 3,94 atau persentase sebesar $98,61 \%$ dengan kategori "baik".
Aspek Kelayakan Penyajian

Berdasarkan Tabel 3, hasil validasi yang dilakukan ahli materi pada aspek kelayakan penyajian dapat diketahui bahwa validasi ahli materi 1 memperoleh skor rata-rata 3,77 atau persentase sebesar 94,23\% dengan kategori “baik”, sedangkan 
Tabel 5. Data Validasi Ahli Materi 1 dan 2 pada Aspek Kelayakan Kegrafikan

\begin{tabular}{|c|c|c|c|}
\hline \multirow[b]{2}{*}{ No. } & \multirow[b]{2}{*}{ Indikator Penilaian } & \multicolumn{2}{|c|}{ Skor } \\
\hline & & $\begin{array}{c}\text { Ahli } \\
\text { Materi 1 }\end{array}$ & $\begin{array}{c}\text { Ahli } \\
\text { Materi } 2\end{array}$ \\
\hline 1. & Kesesuaian ukuran buku dengan standar ISO & 4 & 4 \\
\hline 2. & Kesesuaian ukuran buku dengan materi isi buku & 4 & 4 \\
\hline 3. & Tata letak & 4 & 4 \\
\hline 4. & Tipografi kulit buku & 3 & 4 \\
\hline 5. & Penggunaan huruf & 4 & 4 \\
\hline 6. & Pencerminan isi buku & 4 & 4 \\
\hline 7. & Keharmonisan tata letak & 3 & 3 \\
\hline 8. & Kelengkapan tata letak & 3 & 4 \\
\hline 9. & Daya pemahaman tata letak & 3 & 3 \\
\hline 10. & Tipografi isi buku & 3 & 4 \\
\hline 11. & Ilustrasi isi & 3 & 3 \\
\hline & Jumlah & 38 & 41 \\
\hline & Skor Rata-Rata & 3,45 & 3,73 \\
\hline & Persentase & $86,36 \%$ & $93,18 \%$ \\
\hline & Kategori & Baik & Baik \\
\hline
\end{tabular}

Tabel 6. Data Skor Rata-Rata Validasi Ahli Materi 1 dan 2 pada Keseluruhan Aspek

\begin{tabular}{|c|c|c|c|c|}
\hline Validator & No. & $\begin{array}{c}\text { Aspek } \\
\text { Penilaian }\end{array}$ & $\begin{array}{c}\text { Skor } \\
\text { Rata-Rata }\end{array}$ & Kategori \\
\hline \multirow[t]{2}{*}{1} & $\begin{array}{l}1 . \\
2 . \\
3 . \\
4 .\end{array}$ & $\begin{array}{l}\text { Kelayakan isi } \\
\text { Kelayakan penyajian } \\
\text { Kelayakan bahasa } \\
\text { Kelayakan kegrafikan }\end{array}$ & $\begin{array}{l}3,67 \\
3,77 \\
3,83 \\
3,45\end{array}$ & $\begin{array}{l}\text { Baik } \\
\text { Baik } \\
\text { Baik } \\
\text { Baik }\end{array}$ \\
\hline & & $\begin{array}{c}\text { Jumlah } \\
\text { Skor Rata-Rata } \\
\text { Persentase } \\
\end{array}$ & $\begin{array}{l}14,72 \\
3,68 \\
92 \% \\
\end{array}$ & $\begin{array}{l}\text { Baik } \\
\text { Baik }\end{array}$ \\
\hline Validator & No. & $\begin{array}{c}\text { Aspek } \\
\text { Penilaian }\end{array}$ & $\begin{array}{c}\text { Skor } \\
\text { Rata-Rata }\end{array}$ & Kategori \\
\hline \multirow[t]{2}{*}{2} & $\begin{array}{l}1 . \\
2 . \\
3 . \\
4 .\end{array}$ & $\begin{array}{l}\text { Kelayakan isi } \\
\text { Kelayakan penyajian } \\
\text { Kelayakan bahasa } \\
\text { Kelayakan kegrafikan }\end{array}$ & $\begin{array}{l}3,94 \\
3,92 \\
3,83 \\
3,73 \\
\end{array}$ & $\begin{array}{l}\text { Baik } \\
\text { Baik } \\
\text { Baik } \\
\text { Baik } \\
\end{array}$ \\
\hline & & $\begin{array}{c}\text { Jumlah } \\
\text { Skor Rata-Rata } \\
\text { Persentase }\end{array}$ & $\begin{array}{c}15,42 \\
3.85 \\
96,37\end{array}$ & $\begin{array}{l}\text { Baik } \\
\text { Baik }\end{array}$ \\
\hline
\end{tabular}

pada validasi ahli materi 2 memperoleh skor rata-rata 3,92 atau persentase sebesar 98,08\% dengan kategori "baik".

\section{Aspek Kelayakan Bahasa}

Berdasarkan Tabel 4, hasil validasi pada aspek kelayakan bahasa diketahui 
bahwa validasi ahli materi 1 memperoleh skor rata-rata 3,83 dan persentase sebesar 95,83\% dengan kategori "baik". Sementara itu, hasil validasi ahli materi 2 memperoleh skor rata-rata 3,83 dan sebesar 95,83\% dengan kategori "baik".

\section{Aspek Kelayakan Kegrafikan}

Berdasarkan Tabel 5, hasil validasi pada aspek kelayakan kegrafikan diketahui bahwa validasi yang dilakukan oleh ahli materi 1 memperoleh skor ratarata 3,45 atau persentase sebesar 86,36 $\%$ dengan kategori "baik", sedangkan pada validasi yang dilakukan oleh ahli materi 2 memperoleh skor rata-rata 3,73 atau persentase sebesar $93,18 \%$ dengan kategori "baik".
Berdasarkan uraian hasil validasi oleh ahli materi dari masing-masing aspek, didapatkan skor rata-rata ahli materi 1 dan 2 yang disajikan pada tabel 6 .

Pada Tabel 6. dapat diketahui skor rata-rata validasi ahli materi 1 dan 2 pada keseluruhan aspek penilaian. Skor rata-rata pada ahli materi 1 yaitu 3,68 atau persentase sebesar $92.00 \%$ dengan skor rata-rata dan persentase berkategori "baik". Pada ahli materi 2, skor rata-rata yang diperoleh yaitu 3,85 atau persentase sebesar 96,37 dengan kategori "baik".

Dari skor rata-rata yang diperoleh pada penilaian ahli materi 1 dan 2, maka diperoleh skor rata-rata dari keempat aspek penilaian seperti tabel 7 .

Tabel 8. Data Validasi Ahli Pembelajaran 1 dan 2 pada Aspek Kelayakan Isi

\begin{tabular}{|c|c|c|c|}
\hline \multirow[b]{2}{*}{ No. } & \multirow[b]{2}{*}{ Indikator Penilaian } & \multicolumn{2}{|c|}{ Skor } \\
\hline & & $\begin{array}{l}\text { Ahli } \\
\text { Pembelajaran 1 }\end{array}$ & $\begin{array}{c}\text { Ahli } \\
\text { Pembelajaran } 2\end{array}$ \\
\hline 1. & Kelengkapan materi & 4 & 4 \\
\hline 2. & Keluasan materi & 4 & 4 \\
\hline 3. & Kedalaman materi & 4 & 4 \\
\hline 4. & Akurasi konsep dan definisi & 4 & 4 \\
\hline 5. & Akurasi prinsip & 4 & 4 \\
\hline 6. & Akurasi prosedur & 4 & 4 \\
\hline 7. & Akurasi contoh, fakta, dan ilustrasi & 4 & 4 \\
\hline 8. & Akurasi soal/penugasan & 4 & 4 \\
\hline 9. & $\begin{array}{l}\text { Kesesuaian dengan perkembangan ilmu } \\
\text { dan teknologi }\end{array}$ & 4 & 4 \\
\hline 10. & Keterkinian fitur, contoh, dan rujukan & 4 & 3 \\
\hline 11. & Penalaran & 4 & 4 \\
\hline 12. & Pemecahan masalah & 4 & 4 \\
\hline 13. & Keterkaitan antar-konsep & 4 & 4 \\
\hline 14. & Komunikasi & 4 & 4 \\
\hline 15. & Penerapan & 3 & 3 \\
\hline 16. & Kemenarikan materi & 3 & 4 \\
\hline 17. & $\begin{array}{l}\text { Mendorong untuk mencari informasi } \\
\text { lebih jauh }\end{array}$ & 4 & 3 \\
\hline 18. & Materi pengayaan & 4 & 4 \\
\hline \multicolumn{2}{|c|}{ Jumlah } & 70 & 69 \\
\hline \multicolumn{2}{|c|}{ Skor rata-rata } & 3,89 & 3,83 \\
\hline \multicolumn{2}{|c|}{ Persentase } & $97,20 \%$ & $95,83 \%$ \\
\hline \multicolumn{2}{|c|}{ Kategori } & Baik & Baik \\
\hline
\end{tabular}


Tabel 7. Data Skor Rata-Rata Validasi Ahli Materi pada Keseluruhan Aspek

\begin{tabular}{clc}
\hline No. & \multicolumn{1}{c}{$\begin{array}{c}\text { Aspek } \\
\text { Penilaian }\end{array}$} & $\begin{array}{c}\text { Ahli } \\
\text { Materi }\end{array}$ \\
\hline 1. & Kelayakan Isi & 3,85 \\
2. & Kelayakan Penyajian & 3,84 \\
3. & Kelayakan Bahasa & 3,83 \\
4. & Kelayakan Kegrafikan & 3,59 \\
\hline & Jumlah & $\mathbf{1 5 , 1 1}$ \\
& Skor Rata-Rata & $\mathbf{3 , 7 8}$ \\
& Kategori & Baik \\
\hline
\end{tabular}

Berdasarkan Tabel 7. skor rata-rata yang diperoleh dari penilaian ahli materi pada keseluruhan aspek adalah 3,78 dengan kategori "baik". Ahli materi juga memberi masukan berupa komentar dan saran pada tiap aspek. Pada aspek isi, saran yang diberikan adalah kedalaman, perkembangan iptek, penalaran, metode pencerahan masalah, dan penerapan perlu diperhatikan. Pada aspek penya- jian, komentar yang diberikan adalah belum semua lengkap. Pada aspek bahasa, saran yang diberikan adalah panjang kalimat perlu diperhatikan. Pada aspek kegrafikan, saran yang diberikan adalah kegrafikan dan kulit buku perlu dicermati lagi. Komentar dan saran secara umum terhadap produk tersebut adalah buku sudah baik, tetapi dalam beberapa hal perlu diperhatikan.

\section{Hasil Penilaian Produk oleh Ahli Pem- belajaran}

Uji validasi pada produk ini dilakukan menggunakan lembar angket/kuesioner yang di dalamnya meliputi aspek-aspek penilaian yaitu aspek kelayakan isi, aspek kelayakan bahasa, aspek kelayakan penyajian, dan aspek kelayakan kegrafikan. Uji validasi produk juga dilakukan oleh ahli pembelajaran. Ahli pembelajaran untuk penilaian bahan ajar ini adalah dua orang guru mata pelajaran Bahasa Indonesia SMP. Berikut ini disajikan hasil validasi dalam tiap aspek.

Tabel 9. Data Validasi Ahli Pembelajaran 1 dan 2 pada Aspek Kelayakan Penyajian

\begin{tabular}{|c|c|c|c|}
\hline \multirow[b]{2}{*}{ No. } & \multirow[b]{2}{*}{ Indikator Penilaian } & \multicolumn{2}{|c|}{ Skor } \\
\hline & & $\begin{array}{c}\text { Ahli } \\
\text { Pembelajaran 1 }\end{array}$ & $\begin{array}{c}\text { Ahli } \\
\text { Pembelajaran 2 } \\
\end{array}$ \\
\hline 1. & Sistematika penyajian & 4 & 4 \\
\hline 2. & Keruntutan penyajian & 4 & 4 \\
\hline 3. & Keseimbangan antar-bab & 4 & 4 \\
\hline 4. & Berpusat pada siswa & 4 & 4 \\
\hline 5. & Berpikir kritis, kreatif, atau inovatif & 4 & 4 \\
\hline 6. & Kata Pengantar & 4 & 4 \\
\hline 7. & Daftar Isi & 4 & 4 \\
\hline 8. & Gambar, ilustrasi, atau tabel & 3 & 4 \\
\hline 9. & Rujukan & 4 & 4 \\
\hline 10. & Soal/latihan & 4 & 4 \\
\hline 11. & Daftar Pustaka & 4 & 4 \\
\hline 12. & Glosarium (daftar istilah) & 3 & 3 \\
\hline 13. & Petunjuk pengerjaan soal/latihan & 4 & 4 \\
\hline \multicolumn{2}{|c|}{ Jumlah } & 50 & 51 \\
\hline \multicolumn{2}{|c|}{ Skor rata-rata } & 3,85 & 3,92 \\
\hline \multicolumn{2}{|c|}{ Persentase } & $96,15 \%$ & $98,08 \%$ \\
\hline \multicolumn{2}{|c|}{ Kategori } & Baik & Baik \\
\hline
\end{tabular}




\section{Aspek Kelayakan Isi}

Berdasarkan Tabel 8, hasil validasi aspek kelayakan isi oleh ahli pembelajaran dapat diketahui bahwa skor rata-rata dari ahli pembelajaran 1 yaitu 3,89 atau persentase sebesar 97,20\% dengan kategori "baik", sedangkan skor rata-rata dari ahli pembelajaran 2 yaitu 3,83 atau persentase sebesar 95,83\%dengan kategori "baik".

\section{Aspek Kelayakan Penyajian}

Berdasarkan Tabel 9, hasil validasi aspek kelayakan penyajian oleh ahli pembelajaran dapat diketahui bahwa skor rata-rata dari ahli pembelajaran 1 yaitu 3,85 atau persentase sebesar $96,15 \%$ dengan kategori "baik", sedangkan skor rata-rata dari ahli pembelajaran 2 yaitu 3,92 atau persentase sebesar $98,08 \%$ dengan kategori "baik".

Tabel 10. Data Validasi Guru 1 dan 2 pada Aspek Kelayakan Bahasa

\begin{tabular}{llcc} 
No. Indikator Penilaian & $\begin{array}{c}\text { Ahli } \\
\text { Pembelajaran 1 }\end{array}$ & $\begin{array}{c}\text { Ahli } \\
\text { Pembelajaran 2 }\end{array}$ \\
\cline { 1 - 3 } & 4 & 4 \\
1. Kesesuaian dengan tingkat perkembangan & & 4 \\
$\quad$ intelektual & 4 & 4 \\
2. Kesesuaian dengan tingkat sosial emosional & 4 & 4 \\
3. Keterbacaan pesan & 3 & 3 \\
4. Ketepatan kaidah bahasa & 4 & 4 \\
5. Keruntutan dan keterpaduan antar-bab & 4 & $\mathbf{2 4}$ \\
6. Keruntutan dan keterpaduan antar-paragraf & $\mathbf{2 3}$ & 3,83 \\
\hline Jumlah & 3,83 & $\mathbf{9 5 , 8 3 \%}$ \\
Skor rata-rata & $\mathbf{9 5 , 8 3 \%}$ & \\
Persentase & & \\
Kategori & & \\
\hline
\end{tabular}

Tabel 11. Data Validasi Ahli Pembelajaran 1 dan 2 pada Aspek Kelayakan Kegrafikan

\begin{tabular}{|c|c|c|c|}
\hline \multirow[b]{2}{*}{ No. } & \multirow[b]{2}{*}{ Indikator Penilaian } & \multicolumn{2}{|c|}{ Skor } \\
\hline & & $\begin{array}{c}\text { Ahli } \\
\text { Pembelajaran } 1\end{array}$ & $\begin{array}{c}\text { Ahli } \\
\text { Pembelajaran 2 }\end{array}$ \\
\hline 1. & Kesesuaian ukuran buku dengan standar ISO & 4 & 4 \\
\hline 2. & Kesesuaian ukuran buku dengan materi isi buku & 4 & 4 \\
\hline 3. & Tata letak & 4 & 4 \\
\hline 4. & Tipografi kulit buku & 4 & 4 \\
\hline 5. & Penggunaan huruf & 4 & 4 \\
\hline 6. & Pencerminan isi buku & 4 & 4 \\
\hline 7. & Keharmonisan tata letak & 3 & 3 \\
\hline 8. & Kelengkapan tata letak & 3 & 4 \\
\hline 9. & Daya pemahaman tata letak & 3 & 3 \\
\hline 10. & Tipografi isi buku & 4 & 3 \\
\hline 11. & Ilustrasi isi & 3 & 3 \\
\hline \multicolumn{2}{|c|}{ Jumlah } & 40 & 40 \\
\hline \multicolumn{2}{|c|}{ Skor rata-rata } & 3,64 & 3,64 \\
\hline \multicolumn{2}{|c|}{ Persentase } & $90,90 \%$ & $90,90 \%$ \\
\hline \multicolumn{2}{|c|}{ Kategori } & Baik & Baik \\
\hline
\end{tabular}

LITERA, Volume 16, Nomor 1, April 2017 
Tabel 12. Data Skor Rata-Rata Validasi Ahli Pembelajaran 1 dan 2 pada Seluruh Aspek

\begin{tabular}{|c|c|c|c|c|}
\hline Validator & No. & Aspek Penilaian & $\begin{array}{c}\text { Skor } \\
\text { Rata-Rata }\end{array}$ & Kategori \\
\hline \multirow{7}{*}{1} & 1. & Kelayakan isi & 3,89 & Baik \\
\hline & 2. & Kelayakan penyajian & 3,85 & Baik \\
\hline & 3. & Kelayakan bahasa & 3,83 & Baik \\
\hline & 4. & Kelayakan kegrafikan & 3,64 & Baik \\
\hline & \multicolumn{2}{|c|}{ Jumlah } & 15,21 & \\
\hline & \multicolumn{2}{|c|}{ Skor rata-rata } & 3,80 & Baik \\
\hline & \multicolumn{2}{|c|}{ Persentase } & $95,06 \%$ & Baik \\
\hline \multirow{7}{*}{2} & 1. & Kelayakan isi & 3,83 & Baik \\
\hline & 2. & Kelayakan penyajian & 3,92 & Baik \\
\hline & 3. & Kelayakan bahasa & 3,83 & Baik \\
\hline & 4. & Kelayakan kegrafikan & 3,64 & Baik \\
\hline & \multicolumn{2}{|c|}{ Jumlah } & 15,22 & \\
\hline & \multicolumn{2}{|c|}{ Skor rata-rata } & 3,80 & Baik \\
\hline & \multicolumn{2}{|c|}{ Persentase } & $95,12 \%$ & Baik \\
\hline
\end{tabular}

\section{Aspek Kelayakan Bahasa}

Berdasarkan Tabel 10, hasil validasi aspek kelayakan bahasa oleh ahli pembelajaran dapat diketahui bahwa skor ratarata dari ahli pembelajaran 1 yaitu 3,83 atau persentase sebesar $95,83 \%$ dengan kategori "baik", sedangkan skor rata-rata dari ahli pembelajaran 2 yaitu 3,83 atau persentase sebesar 95,83 dengan kategori "baik".

\section{Aspek Kelayakan Kegrafikan}

Berdasarkan Tabel 11, hasil validasi aspek kelayakan bahasa oleh ahli pembelajaran dapat diketahui bahwa skor ratarata dari ahli pembelajaran 1 yaitu 3,64 atau persentase sebesar $90,90 \%$ dengan kategori "baik", sedangkan skor ratarata dari ahli pembelajaran 2 yaitu 3,64 atau persentase sebesar $90,90 \%$ dengan kategori "baik".

Berdasarkan uraian hasil validasi kedua ahli pembelajaran tersebut, diperoleh data skor rata-rata hasil validasi ahli pembelajaran 1 dan 2 dapat dilihat pada tabel 12.

Berdasarkan Tabel 12, hasil skor yang diperoleh ahli pembelajaran 1 berjumlah 15,21 dengan skor rata-rata 3,80 atau persentase sebesar $95,06 \%$ dan berkategori "baik", sedangkan jumlah skor yang diperoleh dari ahli pembelajaran 2 yaitu 15,22 dengan skor rata-rata 3,80 atau persentase sebesar 95,12 dan berkategori "baik".

Tabel 13.Data Skor Rata-Rata Validasi Ahli Pembelajaran pada Keseluruhan Aspek

\begin{tabular}{clc}
\hline No. & $\begin{array}{c}\text { Aspek } \\
\text { Penilaian }\end{array}$ & $\begin{array}{c}\text { Ahli } \\
\text { Pembelajaran }\end{array}$ \\
\hline 1. & $\begin{array}{l}\text { Kelayakan } \\
\text { Isi }\end{array}$ & 3,86 \\
2. & $\begin{array}{l}\text { Kelayakan } \\
\text { Penyajian }\end{array}$ & 3,88 \\
3. & $\begin{array}{l}\text { Kelayakan } \\
\text { Bahasa }\end{array}$ & 3,83 \\
4. & $\begin{array}{l}\text { Kelayakan } \\
\text { Kegrafikan }\end{array}$ & 3,64 \\
\hline \multicolumn{3}{l}{ Jumlah } \\
Skor Rata-Rata & $\mathbf{1 5 , 2 1}$ \\
Kategori & $\mathbf{3 , 8 0}$ \\
\hline
\end{tabular}

Berdasarkan Tabel 13. skor rata-rata yang diperoleh dari penilaian ahli pembelajaran pada keseluruhan aspek adalah 3,80 dengan kategori "baik". Ahli pem- 
belajaran juga memberi masukan berupa komentar dan saran pada tiap aspek. Pada aspek isi, saran yang diberikan adalah penerapan dan kemenarikan maeri perlu diperhatikan. Pada aspek penyajian, saran yang diberikan adalah glosarium perlu dilengkapi. Pada aspek bahasa, saran yang diberikan adalah kaidah kebahasaan perlu dicermati kembali. Pada aspek kegrafikan, saran yang diberikan adalah kergrafikaan perlu ditata ulang. Komentar dan saran secara umum terhadap produk tersebut adalah buku sudah baik, perlu revisi pada bagian tertentu.

\section{Pembahasan}

Data hasil penelitian terkait produk buku ajar membaca pemahaman baik dari ahli materi maupun ahli pembelajaran membuktikan bahwa buku ajar yang dikembangkan termasuk dalam kategori baik. Hal ini dapat dilihat pada tabel 7 yang menunjukkan skor rata-rata keseluruhan aspek penilaian dari ahli materi sebesar 3,78. Demikian pula penilaian dari ahli pembelajaran menunjukkan skor rata-rata 3,8 seperti ditunjukkan pada tabel 13.

Hasil penilaian yang dilakukan oleh ahli materi menunjukkan bahwa buku ajar membaca pemahaman yang dikembangkan berkategori baik dari aspek kelayakan isi. Ahli materi memberikan skor rata-rata pada aspek kelayakan isi sebesar 3.85 seperti ditunjukkan pada tabel 7. Hal ini berarti buku ajar membaca pemahaman yang dikembangkan memenuhi kriteria kelayakan dari aspek kelayakan isi yang merupakan salah satu persyaratan yang harus dipenuhi oleh sebuah buku ajar.

Penilaian yang dilakukan oleh ahli pembelajaran terkait aspek kelayakan isi menunjukkan bahwa buku ajar yang dikembangkan berakegori baik. Ahli pembelajaran memberikan skor rata-rata sebesar 3.83 pada aspek kelayakan bahasa seperti tercantum pada tabel 13. Hal ini berarti aspek kelayakan bahasa pada buku ajar yang dikembangkan berkategori baik atau layak. Dengan demikian, dapat dikatakan buku tersebut layak digunakan sebagai bahan pembelajaran membaca pemahaman di sekolah dalam hal ini SMP kelas VII.

Hasil penilaian ahli materi terkait aspek kelayakan penyajian menunjukkan bahwa buku ajar membaca pemahaman yang dikembangkan berkategori baik. Hal ini dapat dilihat dari skor rata-rata yang diberikan oleh ahli materi. Berdasar tabel 7 skor rata-rata aspek kelayakan penyajian yang dilakukan oleh ahli materi sebesar 3.84. Hal ini berarti buku ajar yang dikembangkan layak digunakan.

Selanjutnya, penilaian yang dilakukan oleh ahli pembelajaran terkait aspek kelayakan penyajian menunjukkan menunjukkan skor rata-rata sebesar 3.88 seperti ditunjukkan pada tabel 13. Hal ini dapat diartikan bahwa dilihat dari aspek kelayakan penyajian buku ajar yang dikembangkan memenuhi kriteria baik. Hal ini berarti buku tersebut layak digunakan dalam pembelajaan membaca pemahaman di sekolah.

Aspek berikutnya dalam penilaian buku ajar adalah kelayakan bahasa. Penilaian terhadap kelayakan bahasa yang dilakukan oleh ahli materi menunjukkan bahwa buku ajar yang dikembangkan termasuk dalam kategori baik. Hal ini dapat dilihat pada tabel 7 yang menunjukkan bahwa skor rata-rata aspek kelayakan bahasa yang dilakukan oleh ahli materi sebesar 3.83. Hal ini berarti buku tersebut memenuhi kriteria kelayakan dari aspek kelayakan bahasa.

Penilaian yang dilakukan oleh ahli pembelajaran terkait aspek kelayakan bahasa menunjukkan bahwa buku ajar yang dikembangkan berakegori baik. Ahli pembelajaran memberikan skor rata-rata sebesar 3.86 pada aspek kelayakan bahasa seperti tercantum pada tabel 13. Hal ini berarti aspek kelayakan isi pada buku ajar yang dikembangkan berkategori baik 
atau layak. Hal ini berarti juga buku ajar yang dikembangkan layak digunakan sebagai bahan pembelajaran membaca pemahaman di sekolah dalam hal ini SMP kelas VII.

Aspek terakhir dalam penilaian buku ajar adalah kelayakan kegrafikaan. Penilaian terhadap kelayakan kegrafikaan yang dilakukan oleh ahli materi menunjukkan bahwa buku ajar yang dikembangkan termasuk dalam kategori baik. Hal ini dapat dilihat pada tabel 7 yang menunjukkan bahwa skor rata-rata aspek kelayakan kegrafikaan yang dilakukan oleh ahli materi sebesar 3.59. Hal ini berarti buku tersebut memenuhi kriteria baik dan layak dari aspek kelayakan kegrafikaan.

Penilaian aspek kelayakan kegrafikaan juga dilakukan oleh ahli pembelajaran seperti aspek-aspek yang lain. Penilaian yang dilakukan oleh ahli pembelajaran terkait aspek kelayakan kegrafikaan menunjukkan bahwa buku ajar yang dikembangkan berakegori baik. Ahli pembelajaran memberikan skor rata-rata sebesar 3.64 pada aspek kelayakan kegrafikaan seperti tercantum pada tabel 13. Hal ini berarti aspek kelayakan isi pada buku ajar yang dikembangkan berkategori baik atau layak. Hal ini berarti juga buku ajar yang dikembangkan layak digunakan sebagai bahan pembelajaran membaca pemahaman di sekolah dalam hal ini SMP kelas VII.

Sesuai rencana buku ajar membaca pemahaman yang dikembangkan didasarkan pada strategi PLAN yang merupakan salah satu straegi dalam membaca pemahaman. Strategi ini merupakan salah satu strategi yang tepat dalam pembelajaran membaca khususnya meningkatkan pemahaman siswa terhadap teks sains atau nonsastra (Cohen dan Cowen, 2008:219). Selain itu, PLAN juga memberikan kesempatan pada siswa untuk menjelaskan dan mengelaborasi pengetahuan yang dimiliki dengan informasi yang baru saja diperoleh dari teks. Kemudian mereka diminta untuk memprediksi dengan membuat peta konsep prediksi

Menurut Caverly, Mandeville, dan Nicholson !1995:191) strategi PLAN mengombinasikan beberapa kegiatan memprediksi dan membuat peta konsep. PLAN dimulai dengan kegiatan siswa membuat peta konsep berdasarkan prediksi mereka tentang apa yan akan dibaca. Kemudian, mereka diminta untuk memprediksi dengan membuat peta konsep prediksi. Setelah membuat peta konsep prediksi, selanjutnya menempatkan informasi yang sudah dan belum mereka ketahui, dilanjutkan menambahkan kata, frasa, atau gagasan pada peta konsep prediksi untuk melengkapi informasi. Langkah terakhir adalah mencatat apa yang telah mereka pelajari dengan merevisi peta konsep, membuat bahan presentasi baru, menuliskan di jurnal, atau berdiskusi dalam kelompok kecilatau diskusi kelas.

Dalam pengembangan buku ajar membaca pemahaman, kegiatan pembelajaan membaca pemahaman disesuaikan dengan langkah-langkah strategi PLAN. Langkah-langkah tersebut adalah yakni memprediksi, menempatkan, membaca, menambahkan, dan mencatat. Pada setiap unit pelajaran dalam buku yang dikembangkan dilengkapi dengan latihan, pengayaan, dan soal pemahaman bacaan.

\section{SIMPULAN}

Berdasar hasil penelitian dan pembahasan dapat disimpulkan sebagai berikut. Pertama, buku ajar membaca pemahaman yang dihasilkan terdiri dari bagian pendahuluan, isi, dan pelengkap. Bagian pendahuluan berupa kulit atau sampul buku, kata pengantar, dan daftar isi, dan berkenalan dengan strategi PLAN. Bagian isi terdiri atas enam unit pelajaran membaca pemahaman, yaitu: (1) teks deskripsi, (2) teks cerita fantasi, (3) teks prosedur, (4) teks laporan hasil observasi, (5) teks fabel/legenda, dan (6) surat dinas. Pada setiap unit pelaja- 
ran disusun berdasar langkah-langkah strategi PLAN yang terdiri atas beberapa tahap, yakni memprediksi, menempatkan, membaca, menambahkan, dan mencatat. Bahan ajar ini juga dilengkapi dengan latihan pada setiap unit pelajaran. Bagian pelengkap berisi daftar pustaka dan glosarium.

Kedua, hasil uji ahli materi dan ahli pembelajaran menunjukkan buku ajar yang dikembangkan berkategori baik atau layak dari aspek kelayakan isi, kelayakan penyajian, kelayakan bahasa, dan kelayakan kegrafikaan. Hal ini ditunjukkan oleh skor rata-rata yang diperoleh dari ahli materi sebesar 3,78 dan ahli pembelajaran sebesar 3,80.

\section{UCAPAN TERIMA KASIH}

Peneliti mengucapkan terima kasih kepada FBS Universitas Negeri Yogyakarta yang telah membiayai penelitian ini. Selain itu, peneliti juga mengucapkan terima kasih kepada guru-guru Bahasa Indonesia SMP Kota Yogyakarta serta teman dosen sejawat yang telah berkenan menjadi validator ahli.

\section{DAFTAR PUSTAKA}

Alwasilah, A. Ch. (2005). Peningkatan penggunaan bahasa ilmiah dalam membangun budaya menulis. Dalam Pangesti Wiedarti (ed.), Мепији Виdaya Menulis Suatu Bunga Rampai (pp. 3-7). Yogyakarta: Tiara Wacana.

Borg, W.R. and Meredith Damien Gall. (1983). Educational research: an introduction. New York \& London: Longman.

Cladwell, J.S. (2008). Comprehension assessment: a classroom guide. New York: The Guilford Press.

Crawford, J. (2002). The role a material in language classroom. Dalam Richard, J.C., \& Renandya, W.A. (eds.). Methodology in language teaching: an anthology of current practice. Cambridge: Cambridge University Press.
Elly, W.B. (1992). How in the world do students read, IEA study of reading literacy. Hamburg: The International Association for Evaluation of Education Achievement.

Kurniasih, Imas dan Berlian Sani. (2014). Panduan Membuat Bahan Ajar Buku Teks Pelajaran Sesuai dengan Kurikulum 2013. Srabaya: Kata Pena

Mullis, I.V.S., Martin, M.O., Foy, P., \& Drucker, K.T. 2012. PIRLS 2011 international result in reading. Chelsnut Hill, MA: Boston College.

Muslich, Masnur. (2010) Text Book Writig, Dasar-Dasar Pemahaman, Penulisan, dan Pemakaian Buku Teks. Jakarta: Ar-Ruzz Media.

Nurgiyantoro. 2011. Penilaian Otentik dalam Pembelajaran Bahasa. Yogyakarta: Gadjah Mada University Press.

Ruddell, Martha Rapp. 2005. Teaching Content Reading and Writing. United States of America: John Wiley \& Sons Inc.

Sumarwati dan Purwadi. 2010. "Pembuatan Pertanyaan Awal pada Kegiatan Prabaca untuk Meningkatkan Kemampuan Membaca Intensif". Diksi, 1, Vol.17, hlm. 1-14.

Supriyoko.( 2004, 26 Mei). Kebangkitan pendidikan kita. Kedaulatan Rakyat, $p, 6$.

Suryaman, Maman. 2012. Metodologi Pembelajaran Bahasa. Yogyakarta: UNY Press.

Tomkins, G.E. (2010). Literacy in the $21^{\text {st }}$ century a balanced approach. Fifth Edition. Boston: Allyn \& Bacon.

Tomlinson, B. (1998). Material development in language teaching. Cambridge: Cambridge University Press.

Zuchdi, D. (2012). Terampil membaca dan berkarakter mulia. Yogyakarta: Multi Presindo. 